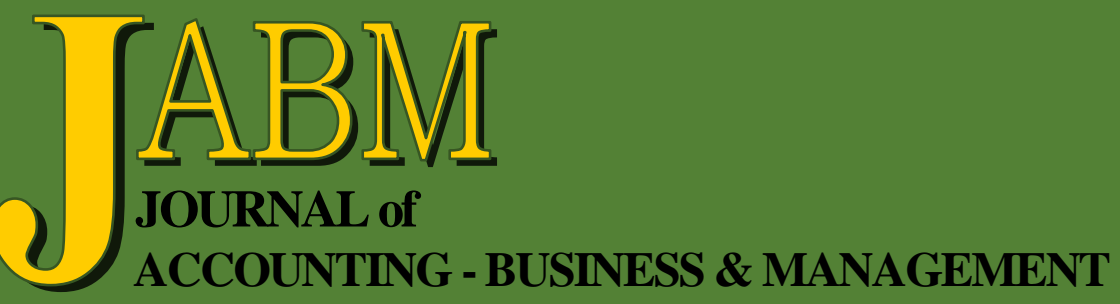

Confidence Crisis in the Application of Cloud Computing in the Industrial Companies in Jordan a Field Study

Abdullah Mohammed Al-Zoubi and Ibtissam Al-Masaiid

Comparative Analysis on Corporate Disclosure Practices of Listed Companies in ASEAN-5 after the Adoption of the Renewal Regional Disclosure Standards

Nunthapin Chantachaimongkol and Shuwen Chen

Capital Structure, Ownership Structure and Corporate Governance of SMEs in Ghana

Ibrahim Anyass Ahmed

The Tax Cuts and Jobs Act and the Middle Class

Deborah Combs and Brian Nichols

The Locus of Innovation: A Literature Review

Yongliang Stanley Han 
Journal of Accounting - Business \& Management vol. 26 no. 1 (2019) 53-61

\title{
The Tax Cuts and Jobs Act and the Middle Class
}

\author{
Deborah Combs* \\ Brian Nicholst
}

\begin{abstract}
This paper explores how the tax cuts and jobs act of 2017 impacts middle-class taxpayers by calculating the tax liability at different levels of income and deductions in 2017 versus 2018. The results confirm the statements supporting the positive effect of the tax change for the middle class.

The tax cut and jobs act eliminates personal exemptions, changes the standard deductions at various incomes and family sizes, and lowers marginal tax rates. After providing details of the act, this research examines the definition of the U.S. middle class by using prior research from the Pew Research Center, the United States Census Bureau, and the federal reserve to determine which income levels are attributable to the middle class. Then the tax liability for these income classes is calculated for single and married filing jointly taxpayers in both 2017 and 2018 to determine if the tax cuts and jobs act reduces the tax liability for the middle class. The results show that in almost all scenarios the tax liability in 2018 will be lower than in 2017, regardless of whether standard or itemized deductions are taken. The marriage penalty is no longer applicable, and the new tax act provides a substantial benefit to large families.
\end{abstract}

Keywords: taxation, income, middle class, tax planning, tax cut and jobs act, tax legislation.

\section{INTRODUCTION}

The United States has had numerous changes to income tax laws, but none more dramatic than the 2018 tax changes, commonly referred to as the tax cuts and jobs act of 20171. These changes provide relief at several levels, especially for the middle class, but when the Tax Cut and Jobs Act was announced many news articles debated if the tax cuts would significantly benefit middle-class taxpayers, or only businesses and the wealthy (Hendrie, 2017; Kessler, 2018).

For individual taxpayers, the existing tax legislation for 2017 provided for personal exemptions of $\$ 4,050$, child tax credits of $\$ 1,000$ per child up to age 17 and level of income, and standard deductions of $\$ 6,350$ for single filers and $\$ 12,700$ for married taxpayers filing jointly. It allowed numerous families to itemize deductions for items such as mortgage interest, state and local taxes, and medical expenses, along with many other deductions, including moving expenses, safety deposit boxes, tax preparation, and hobby losses. Many of these were subject to floors based on adjusted income and phased out at certain income levels of the taxpayer. The personal exemption amounts for 2017 were $\$ 4,050$, the same as in 2016. However, the exemption was subject to a phase-out beginning with adjusted gross incomes of $\$ 261,500$ ( $\$ 313,800$ for married couples filing jointly). The exemption phased out entirely at $\$ 384,000$ ( $\$ 436,300$ for married couples filing jointly).

\footnotetext{
* Missouri Southern State University, Accounting Department. Phone: 417-625-3582. Email: combs-d@mssu.edu.

${ }^{\dagger}$ Missouri Southern State University. Economics \& Finance Department. Phone: 417-625-9599. Email: nichols-b@mssu.edu.
} 
The tax cuts and jobs act decreases the corporate tax rate from $35 \%$ to $21 \%$, but also reduces individual marginal tax rates from tax brackets of 10\%, 15\%, 25\% 28\%, $35 \%$, and $39.6 \%$ to tax brackets of $10 \%, 12 \%, 22 \% 24 \%, 32 \%, 35 \%$, and $37 \%$. It also greatly increases the standard deductions for individual taxpayers and eliminates personal exemptions, making itemization less likely for most taxpayers. Standard deductions increase to $\$ 12,000$ for single filers and $\$ 24,000$ for married couples filing jointly. The new child tax credit doubles to $\$ 2,000$ per qualifying child under the age of 17 , and there is a refundable portion of the child tax credit limited to $\$ 1,400$ per child. This is important for lower- and middle-income families, since the phase-out for the child tax credit begins at $\$ 200,000$ single or $\$ 400,000$ for joint filers, as compared to the 2017 phase-out beginning at $\$ 75,000$ or $\$ 110,000$ respectively. Deductions for student loan interest, excessive medical expenses, state and local taxes up to $\$ 10,000$, and the tax break for graduate students remain intact. It seems clear that lower-income taxpayers who did not itemize deductions will benefit from the tax cuts and jobs act, but will middle-class taxpayers, especially those who itemized deductions in 2017, also see their tax liability reduced in 2018?

In this paper, the different definitions of the U.S. middle class used in past research are discussed to construct a consensus on middle-class income levels. Then the tax liability for both 2017 and 2018 is calculated for six income levels of both single and married filing jointly taxpayers, both with and without children, to determine whether middle-class taxpayers benefit significantly from the tax changes.

Taxpayers who itemized deductions in 2017 are examined to determine if their tax liability will increase or decrease, since the threshold for itemizing is much higher with the new tax act. Breakeven itemized deduction amounts that make the tax liability equal between the 2017 and 2018 tax laws are also determined.

Results show the tax liability for middle-class taxpayers, especially those with children, decreases in all scenarios for those who use the standard deduction. For taxpayers who itemize their deductions, only in the unlikely cases where taxpayers at the lowest income levels have very high itemized deductions will the tax liability increase for those with no children. In all other cases, the tax liability in 2018 will decrease. Our research supports the fact that the tax cuts and jobs act benefits not only businesses and the wealthy but also the middle class.

\section{DEFINING THE MIDDLE CLASS}

The mainstream media often discusses the middle class in the United States, but it is difficult to come to a consensus as to precisely who comprises the middle class (Varner, 2012; Yen, 2012; and Williams, 2014). Even most Americans are undecided only $44 \%$ of Americans identify themselves as middle class, down from 53\% in 2008 (Kochhar \& Morin, 2014). The majority of Americans surveyed by the Pew Research Center state that a secure job and the ability to save money are requirements to be middle class, but only $30 \%$ say a college education is necessary to be middle class (Brown, 2016). The responses suggest there are numerous factors to consider when defining various groups in the United States, such as educational level, net worth, debt burden, age, and ethnicity (Bricker et al., 2017). However, the majority of the literature regarding how to define the middle class focuses on either taxes paid or income.

In some of the literature, the burden of income taxes paid determines the division among the lower, middle, and upper classes. The Pew Research Center research of IRS tax data from 2015 found taxpayers with incomes over $\$ 200,000$ pay the majority of federal income taxes, 58.8 percent. Taxpayers with incomes below 
$\$ 30,000$ only paid $1.4 \%$ of federal income taxes (Desilver, 2017). Research by the Tax Foundation supports this trend; the income tax burden shift to higher earning taxpayers (above $\$ 250,000$ AGI) was from 52 percent in 2013 to 55 in 2014 (Tax Foundation, 2016). Therefore, one definition of the middle class could be taxpayers in the $25 \%$ and $28 \%$ tax brackets. This corresponds to adjusted gross incomes, between $\$ 37,950$ for a single taxpayer to $\$ 233,350$ for married taxpayers filing jointly (IRS, 2017). The IRS data does not consider any economic issues other than income taxes paid.

Much of the research regarding the middle class uses income levels and family size. The Pew Research Center, using data from the 2014 Census Bureau Current Population Survey, defines middle-income Americans as adults whose annual household income is between two-thirds to double the national median income while accounting for household size. This equates to a range between $\$ 24,173$ for a single person and $\$ 162,161$ for a household of five (Pew Research Center, 2015). Through this research, they determined the decline in the middle class in the past years has been substantial; the middle class is no longer considered the majority population nor the majority share of income in the United States. Their research shows a narrowing of the middle class by a "hollowing out" of the middle class with some becoming more economically worse and others rising above the middle class (Pew Research Center, 2015).

The Census Bureau, in their 2017 Current Population Survey, divides household income into quintiles. In 2016, the lowest quintile income limit was $\$ 24,002$ and the upper limit of the fourth quintile was $\$ 121,018$, with the median income being $\$ 59,039$ (U. S. Census Bureau, 2017). This data has been used extensively by economists to define the middle class, but no consensus definition has ever developed - they range anywhere from the middle 20 percent of earnings to incomes between $\$ 25,000$ to $\$ 199,999$ (Reeves et al., 2018).

The Federal Reserve has also performed research on the middle class. Using its 2013 Survey of Consumer Finances, it defined the middle class as either families with annual income between $\$ 24,349$, or the $25^{\text {th }}$ percentile, and $\$ 89,887$, the $75^{\text {th }}$ percentile, or based on wealth, the middle two percentiles including families between $\$ 8,784$ and $\$ 315,715$ of net worth (Emmons \& Noeth, 2015). However, it discusses the fact that these definitions fail to include characteristics such as age, education, and ethnicity. It defines three groups of families headed by someone 40 years of age or older, in which the middle class includes 44 percent of families in the 2013 Survey of Consumer Finances with a head of household who is white or Asian with a high school diploma or black or Hispanic with a two- or four-year college degree. The results of this research show the median income of this group was 16 percent lower in 2013 than in 1989, while the median income of the upper 33 percent of households (termed "thrivers") increased by 2 percent during the same period (Emmons \& Noeth, 2015).

Using IRS data from individual tax returns, in $201536.5 \%$ of the returns came from taxpayers with adjusted gross income of $\$ 25,000$ or less, and $94 \%$ of all returns came from taxpayers with AGI under $\$ 200,000$ (IRS, 2017a). If the middle class should represent the middle or majority of the U.S. population, then the middle class falls somewhere between these amounts (see Figure 1). 
Figure 1

Percentage of Tax Returns Filed by AGI for 2015

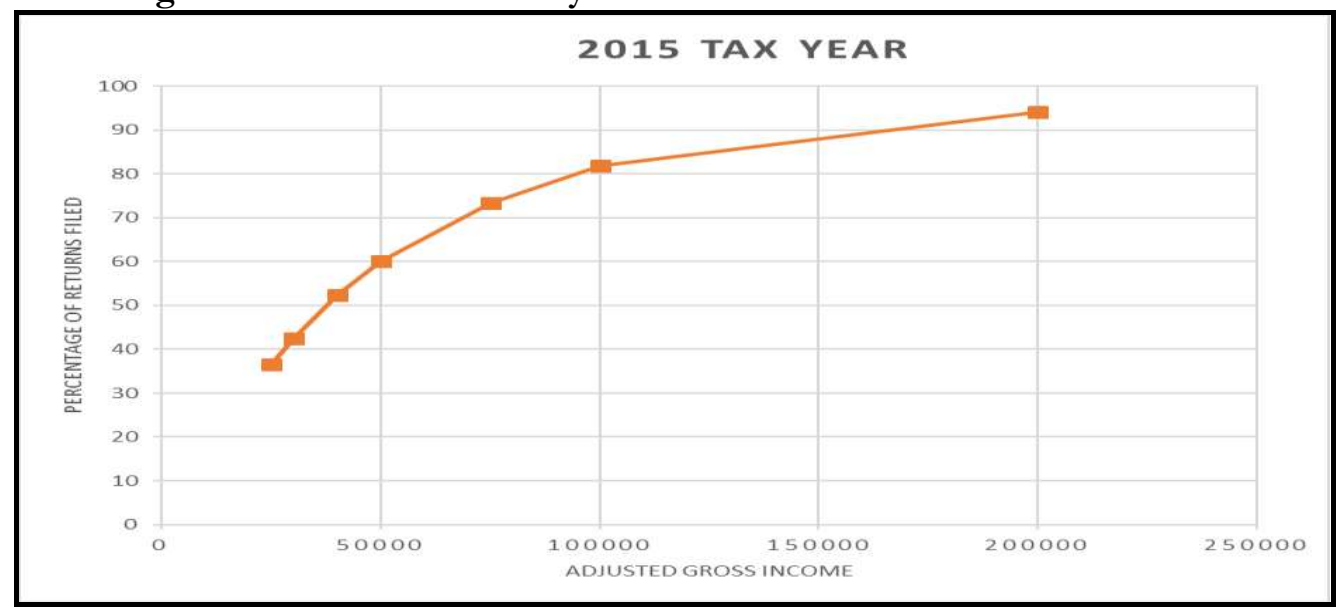

III. THE IMPACT OF THE TAX CUTS AND JOBS ACT ON MIDDLE CLASS TAX LIABILITY

Considering all the various definitions of the middle class above, six adjusted gross income levels beginning at $\$ 25,000$ for single taxpayers or $\$ 50,000$ for married filing jointly taxpayers and increased in $\$ 25,000$ increments, are examined to determine how the tax cuts and jobs act affects the tax liability of middle-class taxpayers. These income levels range from $\$ 25,000$ to $\$ 175,000$, which should encompass most of the definitions of the U.S. middle class. The four filing statuses selected for the analysis were single and married filing jointly (MFJ) with no children, two children, and five children. Comparing similar income and filing statuses between 2017 and 2018 allows for the comparison of the difference in tax liability, emphasizing the tax law changes and their impact on the middle class.

Tax liabilities are calculated using both standard deductions and itemized deductions at amounts ranging from $\$ 10,000$ for single taxpayers to $\$ 30,000$ for married taxpayers filing jointly. The tax cuts and jobs act eliminates personal exemptions but approximately doubles the standard deduction. The change is estimated to reduce the number of taxpayers who itemize deductions by approximately $61 \%$ (Joint Committee on Taxation, 2018), so of particular interest is how the tax act affects the tax liability of those taxpayers who had enough deductions to itemize in 2017 but will not in 2018 due to the expansion of the standard deduction.

Tables 1 through 4 provide comparisons of the tax liability from 2017 to 2018 for single and married filing jointly taxpayers who take the standard deduction of $\$ 6,350 / \$ 12,000$ for individual taxpayers or $\$ 12,700 / \$ 24,000$ for married filing jointly. The results show in all cases the tax liability decreases in 2018, at an average reduction of $15.9 \%$ for single taxpayers or $34.5 \%$ for married filing jointly taxpayers with five children. The percentage change of the tax cut is higher for lower-income taxpayers than for those with larger incomes. The argument stating the tax cuts and jobs act only helps businesses and the wealthy lacks validity.

These tables reflect how significant the 2018 child tax credit changes are for families. The credit increases to $\$ 2,000$ per qualifying child under the age of 17 at the end of the tax year, and there is now a refundable portion of the credit up to $\$ 1,400$ per 
child. This change allows lower-income families to go from either zero tax liability or a small tax payment to a potentially large tax refund.

Table 1

Differences in Taxes Filing Single with No Children using the Standard Deduction

\begin{tabular}{|c|c|c|c|c|c|c|c|c|c|c|c|c|}
\hline Year & 2017 & 2018 & 2017 & 2018 & 2017 & 2018 & 2017 & 2018 & 2017 & 2018 & 2017 & 2018 \\
\hline $\begin{array}{l}\text { Adjusted Gross } \\
\text { Income }\end{array}$ & \multicolumn{2}{|c|}{$\$ 25,000$} & \multicolumn{2}{|c|}{$\$ 50,000$} & \multicolumn{2}{|c|}{$\$ 75,000$} & \multicolumn{2}{|c|}{$\$ 100,000$} & \multicolumn{2}{|c|}{$\$ 125,000$} & \multicolumn{2}{|c|}{$\$ 150,000$} \\
\hline $\begin{array}{l}\text { Personal } \\
\text { Exemptions }\end{array}$ & $\$ 4,050$ & $\$ 0$ & $\$ 4,050$ & $\$ 0$ & $\$ 4,050$ & $\$ 0$ & $\$ 4,050$ & $\$ 0$ & $\$ 4,050$ & $\$ 0$ & $\$ 4,050$ & $\$ 0$ \\
\hline $\begin{array}{l}\text { Standard } \\
\text { Deduction }\end{array}$ & $\$ 6,350$ & $\$ 12,000$ & $\$ 6,350$ & $\$ 12,000$ & $\$ 6,350$ & $\$ 12,000$ & $\$ 6,350$ & $\$ 12,000$ & $\$ 6,350$ & $\$ 12,000$ & $\$ 6,350$ & $\$ 12,000$ \\
\hline Taxable Income & $\$ 14,600$ & $\$ 13,000$ & $\$ 39,600$ & $\$ 38,000$ & $\$ 64,600$ & $\$ 63,000$ & $\$ 89,600$ & $\$ 88,000$ & $\$ 114,600$ & $\$ 113,000$ & $\$ 139,600$ & $\$ 138,000$ \\
\hline $\begin{array}{l}\text { Tax Before } \\
\text { Credits }\end{array}$ & $\$ 1,728$ & $\$ 1,370$ & $\$ 5,645$ & $\$ 4,370$ & $\$ 11,695$ & $\$ 9,800$ & $\$ 18,145$ & $\$ 15,410$ & $\$ 25,070$ & $\$ 21,410$ & $\$ 32,070$ & $\$ 27,410$ \\
\hline Child Tax Credit & $\$ 0$ & $\$ 0$ & $\$ 0$ & $\$ 0$ & $\$ 0$ & $\$ 0$ & $\$ 0$ & $\$ 0$ & $\$ 0$ & $\$ 0$ & $\$ 0$ & $\$ 0$ \\
\hline Tax After Credits & $\$ 1,728$ & $\$ 1,370$ & $\$ 5,645$ & $\$ 4,370$ & $\$ 11,895$ & $\$ 9,800$ & $\$ 18,145$ & $\$ 15,410$ & $\$ 25,070$ & $\$ 21,410$ & $\$ 32,070$ & $\$ 27,410$ \\
\hline $\begin{array}{l}\text { Tax Cut }(-) \text { or } \\
\text { Increase }(+)\end{array}$ & & $-\$ 358$ & & $-\$ 1,275$ & & $-\$ 2,095$ & & $-\$ 2,735$ & & $-\$ 3,660$ & & $-\$ 4,660$ \\
\hline$\%$ Change & & $-20.7 \%$ & & $-22.6 \%$ & & $-17.6 \%$ & & $-15.1 \%$ & & $-14.6 \%$ & & $-14.5 \%$ \\
\hline
\end{tabular}

Table 2

Differences in Taxes Married Filing Jointly with No Children using the Standard Deduction

\begin{tabular}{|c|c|c|c|c|c|c|c|c|c|c|c|c|}
\hline Year & 2017 & 2018 & 2017 & 2018 & 2017 & 2018 & 2017 & 2018 & 2017 & 2018 & 2017 & 2018 \\
\hline $\begin{array}{l}\text { Adjusted Gross } \\
\text { Income }\end{array}$ & \multicolumn{2}{|c|}{$\$ 50,000$} & \multicolumn{2}{|c|}{$\$ 75,000$} & \multicolumn{2}{|c|}{$\$ 100,000$} & \multicolumn{2}{|c|}{$\$ 125,000$} & \multicolumn{2}{|c|}{$\$ 150,000$} & \multicolumn{2}{|c|}{$\$ 175,000$} \\
\hline $\begin{array}{l}\text { Personal } \\
\text { Exemptions }\end{array}$ & $\$ 8,100$ & $\$ 0$ & $\$ 8,100$ & $\$ 0$ & $\$ 8,100$ & $\$ 0$ & $\$ 8,100$ & $\$ 0$ & $\$ 8,100$ & $\$ 0$ & $\$ 8,100$ & $\$ 0$ \\
\hline $\begin{array}{l}\text { Standard } \\
\text { Decuction }\end{array}$ & $\$ 12,700$ & $\$ 24,000$ & $\$ 12,700$ & $\$ 24,000$ & $\$ 12,700$ & $\$ 24,000$ & $\$ 12,700$ & $\$ 24,000$ & $\$ 12,700$ & $\$ 24,000$ & $\$ 12,700$ & $\$ 24,000$ \\
\hline Taxable Income & $\$ 29,200$ & $\$ 26,000$ & $\$ 54,200$ & $\$ 51,000$ & $\$ 79,200$ & $\$ 76,000$ & $\$ 104,200$ & $\$ 101,000$ & $\$ 129,200$ & $\$ 126,000$ & $\$ 154,200$ & $\$ 151,000$ \\
\hline $\begin{array}{l}\text { Tax Before } \\
\text { Credits }\end{array}$ & $\$ 3,451$ & $\$ 2,739$ & $\$ 7,201$ & $\$ 5,739$ & $\$ 11,284$ & $\$ 8,739$ & $\$ 17,528$ & $\$ 14,099$ & $\$ 23,778$ & $\$ 19,599$ & $\$ 30,061$ & $\$ 25,099$ \\
\hline Child Tax Credit & $\$ 0$ & $\$ 0$ & $\$ 0$ & $\$ 0$ & $\$ 0$ & $\$ 0$ & $\$ 0$ & $\$ 0$ & $\$ 0$ & $\$ 0$ & $\$ 0$ & $\$ 0$ \\
\hline Tax After Credits & $\$ 3,451$ & $\$ 2,739$ & $\$ 7,201$ & $\$ 5,739$ & $\$ 11,284$ & $\$ 8,739$ & $\$ 17,528$ & $\$ 14,099$ & $\$ 23,778$ & $\$ 19,599$ & $\$ 30,061$ & $\$ 25,099$ \\
\hline $\begin{array}{l}\text { Tax Cut }(-) \text { or } \\
\text { Increase }(+)\end{array}$ & & $-\$ 712$ & & $-\$ 1,462$ & & $-\$ 2,545$ & & $-\$ 3,428$ & & $-\$ 4,178$ & & $-\$ 4,962$ \\
\hline$\%$ Change & & $-20.6 \%$ & & $-20.3 \%$ & & $-22.6 \%$ & & $-19.6 \%$ & & $-17.6 \%$ & & $-16.5 \%$ \\
\hline
\end{tabular}

Table 3

Differences in Taxes Married Filing Jointly with 2 Children using the Standard Deduction

\begin{tabular}{|c|c|c|c|c|c|c|c|c|c|c|c|c|}
\hline Year & 2017 & 2018 & 2017 & 2018 & 2017 & 2018 & 2017 & 2018 & 2017 & 2018 & 2017 & 2018 \\
\hline $\begin{array}{l}\text { Adjusted Gross } \\
\text { Income }\end{array}$ & \multicolumn{2}{|c|}{$\$ 50,000$} & \multicolumn{2}{|c|}{$\$ 75,000$} & \multicolumn{2}{|c|}{$\$ 100,000$} & \multicolumn{2}{|c|}{$\$ 125,000$} & \multicolumn{2}{|c|}{$\$ 150,000$} & \multicolumn{2}{|c|}{$\$ 175,000$} \\
\hline $\begin{array}{l}\text { Personal } \\
\text { Exemptions }\end{array}$ & $\$ 16,200$ & $\$ 0$ & $\$ 16,200$ & $\$ 0$ & $\$ 16,200$ & $\$ 0$ & $\$ 16,200$ & $\$ 0$ & $\$ 16,200$ & $\$ 0$ & $\$ 16,200$ & $\$ 0$ \\
\hline $\begin{array}{l}\text { Standard } \\
\text { Deduction }\end{array}$ & $\$ 12,700$ & $\$ 24,000$ & $\$ 12,700$ & $\$ 24,000$ & $\$ 12,700$ & $\$ 24,000$ & $\$ 12,700$ & $\$ 24,000$ & $\$ 12,700$ & $\$ 24,000$ & $\$ 12,700$ & $\$ 24,000$ \\
\hline Taxable Income & $\$ 21,100$ & $\$ 26,000$ & $\$ 46,100$ & $\$ 51,000$ & $\$ 71,100$ & $\$ 76,000$ & $\$ 96,100$ & $\$ 101,000$ & $\$ 121,100$ & $\$ 126,000$ & $\$ 146,100$ & $\$ 151,000$ \\
\hline $\begin{array}{l}\text { Tax Before } \\
\text { Credits }\end{array}$ & $\$ 2,236$ & $\$ 2,739$ & $\$ 5,986$ & $\$ 5,739$ & $\$ 9,736$ & $\$ 8,739$ & $\$ 15,509$ & $\$ 14,099$ & $\$ 21,753$ & $\$ 19,599$ & $\$ 28,003$ & $\$ 25,099$ \\
\hline Child Tax Credit & $\$ 2,000$ & $\$ 4,000$ & $\$ 2,000$ & $\$ 4,000$ & $\$ 2,000$ & $\$ 4,000$ & $\$ 1,250$ & $\$ 4,000$ & $\$ 0$ & $\$ 4,000$ & $\$ 0$ & $\$ 4,000$ \\
\hline Tax after Credits & $\$ 236$ & $-\$ 1,261$ & $\$ 3,986$ & $\$ 1,739$ & $\$ 7,736$ & $\$ 4,739$ & $\$ 14,259$ & $\$ 10,099$ & $\$ 21,753$ & $\$ 15,599$ & $\$ 28,003$ & $\$ 21,099$ \\
\hline $\begin{array}{l}\text { Tax Cut }(-) \text { or } \\
\text { Increase }(+)\end{array}$ & & $-\$ 1,497$ & & $-\$ 2,247$ & & $-\$ 2,997$ & & $-\$ 4,160$ & & $-\$ 6,154$ & & $-\$ 6,904$ \\
\hline$\%$ Change & & $-634.3 \%$ & & $-31.2 \%$ & & $-26.6 \%$ & & $-23.7 \%$ & & $-25.9 \%$ & & $-23.0 \%$ \\
\hline
\end{tabular}


Table 4

Differences in Taxes Married Filing Jointly with 5 Children using the Standard Deduction

\begin{tabular}{|l|c|c|c|c|c|c|c|c|c|c|c|c|}
\hline \multicolumn{1}{|c|}{ Year } & 2017 & 2018 & 2017 & 2018 & 2017 & 2018 & 2017 & 2018 & 2017 & 2018 & 2017 & 2018 \\
\hline $\begin{array}{l}\text { Adjusted Gross } \\
\text { Income }\end{array}$ & $\$ 50,000$ & $\$ 75,000$ & $\$ 100,000$ & $\$ 125,000$ & $\$ 150,000$ & $\$ 175,000$ \\
\hline $\begin{array}{l}\text { Personal } \\
\text { Exemptions }\end{array}$ & $\$ 28,350$ & $\$ 0$ & $\$ 28,350$ & $\$ 0$ & $\$ 28,350$ & $\$ 0$ & $\$ 28,350$ & $\$ 0$ & $\$ 28,350$ & $\$ 0$ & $\$ 28,350$ & $\$ 0$ \\
\hline $\begin{array}{l}\text { Standard } \\
\text { Deduction }\end{array}$ & $\$ 12,700$ & $\$ 24,000$ & $\$ 12,700$ & $\$ 24,000$ & $\$ 12,700$ & $\$ 24,000$ & $\$ 12,700$ & $\$ 24,000$ & $\$ 12,700$ & $\$ 24,000$ & $\$ 12,700$ & $\$ 24,000$ \\
\hline Taxable Income & $\$ 8,950$ & $\$ 26,000$ & $\$ 33,950$ & $\$ 51,000$ & $\$ 58,950$ & $\$ 76,000$ & $\$ 83,950$ & $\$ 101,000$ & $\$ 108,950$ & $\$ 126,000$ & $\$ 133,950$ & $\$ 151,000$ \\
\hline $\begin{array}{l}\text { Tax Before } \\
\text { Credits }\end{array}$ & $\$ 898$ & $\$ 2,739$ & $\$ 4,164$ & $\$ 5,739$ & $\$ 7,914$ & $\$ 8,739$ & $\$ 12,471$ & $\$ 14,099$ & $\$ 18,715$ & $\$ 19,599$ & $\$ 24,965$ & $\$ 25,099$ \\
\hline Child Tax Credit & $\$ 898$ & $\$ 9,739$ & $\$ 4,164$ & $\$ 10,000$ & $\$ 5,000$ & $\$ 10,000$ & $\$ 4,250$ & $\$ 10,000$ & $\$ 3,000$ & $\$ 10,000$ & $\$ 1,750$ & $\$ 10,000$ \\
\hline Tax after Credits & $\$ 0$ & $-\$ 7,000$ & $\$ 0$ & $-\$ 4,261$ & $\$ 2,914$ & $-\$ 1,261$ & $\$ 8,221$ & $\$ 4,099$ & $\$ 15,715$ & $\$ 9,599$ & $\$ 23,215$ & $\$ 15,099$ \\
\hline $\begin{array}{l}\text { Tax Cut (-) or } \\
\text { Increase }(+)\end{array}$ & & $-\$ 7,000$ & & $-\$ 4,261$ & & $-\$ 4,175$ & & $-\$ 4,122$ & & $-\$ 6,116$ & & $-\$ 8,116$ \\
\hline$\%$ Change & & $\mathrm{N} / \mathrm{A}$ & & $-59.2 \%$ & & $-37.0 \%$ & & $-23.5 \%$ & & $-25,7 \%$ & & $-27.0 \%$ \\
\hline
\end{tabular}

Of further note is that the tax cuts and jobs act also eliminates the marriage penalty for middle-class taxpayers. For the lowest five marginal tax rates (up to $32 \%$ ), the tax brackets for married filing jointly taxpayers are precisely double those for single taxpayers. Figure 2 shows the tax savings increases proportionately for both single and married filing jointly taxpayers with no children.

Figure 2

Tax Savings by AGI and Filing Status

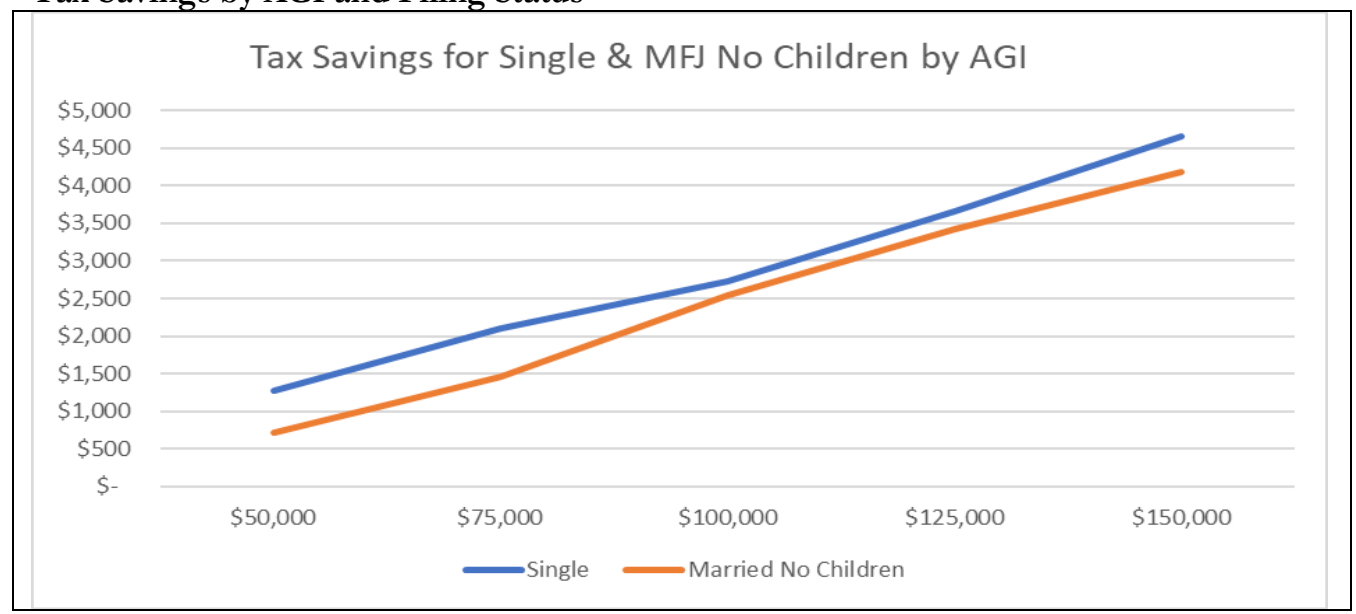

Tables 5 through 8 examine the differences in tax liabilities from 2017 to 2018 for taxpayers who chose to itemize deductions in 2017. Three levels of itemized deductions are used for the calculations: $\$ 10,000, \$ 15,000$, and $\$ 20,000$ for single filers, and $\$ 20,000, \$ 25,000$, and $\$ 30,000$ for taxpayers who are married filing jointly.

Since the standard deduction almost doubled for 2018, those taxpayers who had itemized deductions in 2017 just above the new standard deduction may have cause for concern that their taxes will increase in 2018. The concerns are unjustified. Table 5 shows that in all but the most unlikely cases where a single taxpayer has adjusted gross income of $\$ 25,000$ but is still able to itemize deductions, the tax liability for 2018 will decline. The breakeven itemized deduction, the point at which the tax liability in 2018 equals the tax liability in 2017, is also calculated. In all but the three scenarios mentioned above, the breakeven itemized deduction in 2018 is lower than the itemized deduction taken in 2017, giving further evidence that the tax cuts and jobs act benefits the middle class. 
Table 5

Differences in Taxes Filing Single with no children using Itemized Deductions

\begin{tabular}{|c|c|c|c|c|c|c|}
\hline $\begin{array}{l}\text { Adjusted Gross Income/ } \\
\text { Itemized Deduction }\end{array}$ & $\$ 25,000$ & $\$ 50,000$ & $\$ 75,000$ & $\$ 100,000$ & $\$ 125,000$ & $\$ 150,000$ \\
\hline \multicolumn{7}{|c|}{2017 Taxes by Itemized Deduction } \\
\hline$\$ 10,000$ & $\$ 1,180$ & $\$ 4,930$ & $\$ 10,983$ & $\$ 17,233$ & $\$ 24,048$ & $\$ 31,048$ \\
\hline$\$ 15,000$ & $\$ 598$ & $\$ 4,180$ & $\$ 9,733$ & $\$ 15,983$ & $\$ 22,648$ & $\$ 29,648$ \\
\hline$\$ 20,000$ & $\$ 96$ & $\$ 3,430$ & $\$ 8,483$ & $\$ 14,733$ & $\$ 21,248$ & $\$ 28,248$ \\
\hline \multicolumn{7}{|c|}{2018 Taxes by Standard or Itemized Deduction } \\
\hline$\$ 12,000($ Standard $)$ & $\$ 1,370$ & $\$ 4,370$ & $\$ 9,800$ & $\$ 15,410$ & $\$ 21,410$ & $\$ 27,410$ \\
\hline$\$ 15,000$ & $\$ 1,010$ & $\$ 4,010$ & $\$ 9,140$ & $\$ 14,690$ & $\$ 20,690$ & $\$ 26,690$ \\
\hline$\$ 20,000$ & $\$ 500$ & $\$ 3,410$ & $\$ 8,040$ & $\$ 13,540$ & $\$ 19,490$ & $\$ 25,490$ \\
\hline \multicolumn{7}{|c|}{ Tax Cut (-) or Increase $(+)$} \\
\hline$\$ 10,000$ & $\$ 190$ & $-\$ 561$ & $-\$ 1,183$ & $-\$ 1,823$ & $-\$ 2,638$ & $-\$ 3,638$ \\
\hline$\$ 15,000$ & $\$ 412$ & $-\$ 171$ & $-\$ 593$ & $-\$ 1,293$ & $-\$ 1,958$ & $-\$ 2,958$ \\
\hline$\$ 20,000$ & $\$ 404$ & $-\$ 21$ & $-\$ 443$ & $-\$ 1,193$ & $-\$ 1,758$ & $-\$ 2,758$ \\
\hline \multicolumn{7}{|c|}{ Breakeven Itemized Deduction } \\
\hline$\$ 10,000$ & $\$ 13,579$ & $\$ 7,329$ & $\$ 6,620$ & $\$ 4,402$ & $\$ 1,007$ & $-\$ 3,159$ \\
\hline$\$ 15,000$ & $\$ 18,429$ & $\$ 13,579$ & $\$ 12,302$ & $\$ 9,610$ & $\$ 6,841$ & $\$ 2,674$ \\
\hline$\$ 20,000$ & $\$ 24,040$ & $\$ 19,829$ & $\$ 17,984$ & $\$ 14,575$ & $\$ 12,674$ & $\$ 8,507$ \\
\hline
\end{tabular}

Tables 6 through 8 provide similar results for married taxpayers filing jointly with no children, two children, or five children, respectively. Results in Table 6 are similar to those in Table 5; only married couples with no children who have combined income of $\$ 75,000$ or less and large amounts of itemized deductions will see a slight increase in taxes for 2018. These scenarios seem unlikely since lower-income taxpayers usually do not have enough deductions to warrant itemizing. In all other situations, the tax liability will decrease, and the breakeven itemized deduction is lower in 2018. Tables 7 and 8 show that the tax liability in 2018 for families with children will decrease in all scenarios, regardless of the income or itemized deduction levels. In some situations, the breakeven itemized deduction is even negative, primarily due to the refundable child tax credit and the significant increase in income at which the child tax credit phases out.

Table 6

Differences in Taxes Married Filing Jointly with no Children using Itemized Deductions

\begin{tabular}{|c|c|c|c|c|c|c|}
\hline $\begin{array}{l}\text { Adjusted Gross Income/ } \\
\text { Itemized Deduction }\end{array}$ & $\$ 50,000$ & $\$ 75,000$ & $\$ 100,000$ & $\$ 125,000$ & $\$ 150,000$ & $\$ 175,000$ \\
\hline \multicolumn{7}{|c|}{2017 Taxes by Itemized Deduction } \\
\hline$\$ 20,000$ & $\$ 2,356$ & $\$ 6,106$ & $\$ 9,856$ & $\$ 15,709$ & $\$ 21,953$ & $\$ 28,203$ \\
\hline$\$ 25,000$ & $\$ 1,693$ & $\$ 5,356$ & $\$ 9,106$ & $\$ 14,459$ & $\$ 20,703$ & $\$ 26,953$ \\
\hline$\$ 30,000$ & $\$ 1,193$ & $\$ 4,606$ & $\$ 8,356$ & $\$ 13,209$ & $\$ 19,453$ & $\$ 25,703$ \\
\hline \multicolumn{7}{|c|}{2018 Taxes by Standard or Itemized Deduction } \\
\hline$\$ 24,000($ Standard $)$ & $\$ 2,739$ & $\$ 5,739$ & $\$ 8,599$ & $\$ 14,099$ & $\$ 19,599$ & $\$ 25,099$ \\
\hline$\$ 25,000$ & $\$ 2,619$ & $\$ 5,619$ & $\$ 8,619$ & $\$ 13,879$ & $\$ 19,379$ & $\$ 24,879$ \\
\hline$\$ 30,000$ & $\$ 2,019$ & $\$ 5,019$ & $\$ 8,019$ & $\$ 12,779$ & $\$ 18,279$ & $\$ 23,779$ \\
\hline \multicolumn{7}{|c|}{ Tax Cut $(-)$ or Increase $(+)$} \\
\hline$\$ 20,000$ & $\$ 383$ & $-\$ 367$ & $-\$ 1,257$ & $-\$ 1,610$ & $-\$ 2,354$ & $-\$ 3,104$ \\
\hline$\$ 25,000$ & $\$ 926$ & $\$ 263$ & $-\$ 487$ & $-\$ 580$ & $-\$ 1,324$ & $-\$ 2,074$ \\
\hline$\$ 30,000$ & $\$ 826$ & $\$ 413$ & $-\$ 337$ & $-\$ 430$ & $-\$ 1,174$ & $-\$ 1,924$ \\
\hline \multicolumn{7}{|c|}{ Breakeven Itemized Deduction } \\
\hline$\$ 20,000$ & $\$ 27,192$ & $\$ 20,942$ & $\$ 18,286$ & $\$ 16,682$ & $\$ 13,302$ & $\$ 9,893$ \\
\hline$\$ 25,000$ & $\$ 32,716$ & $\$ 27,192$ & $\$ 20,942$ & $\$ 22,364$ & $\$ 18,984$ & $\$ 15,575$ \\
\hline$\$ 30,000$ & $\$ 36,883$ & $\$ 33,442$ & $\$ 27,192$ & $\$ 28,045$ & $\$ 24,666$ & $\$ 21,257$ \\
\hline
\end{tabular}


Table 7

Differences in Taxes Married Filing Jointly with 2 Children using Itemized Deductions

\begin{tabular}{|c|c|c|c|c|c|c|}
\hline $\begin{array}{l}\text { Adjusted Gross Income/ } \\
\text { Itemized Deduction }\end{array}$ & $\$ 50,000$ & $\$ 75,000$ & $\$ 100,000$ & $\$ 125,000$ & $\$ 150,000$ & $\$ 175,000$ \\
\hline \multicolumn{7}{|c|}{2017 Taxes by Itemized Deduction } \\
\hline$\$ 20,000$ & $\$ 0$ & $\$ 2,891$ & $\$ 6,641$ & $\$ 12,434$ & $\$ 19,928$ & $\$ 26,178$ \\
\hline$\$ 25,000$ & $\$ 0$ & $\$ 2,141$ & $\$ 5,891$ & $\$ 11,184$ & $\$ 18,678$ & $\$ 24,928$ \\
\hline$\$ 30,000$ & $\$ 0$ & $\$ 1,391$ & $\$ 5,141$ & $\$ 9,934$ & $\$ 17,428$ & $\$ 23,678$ \\
\hline \multicolumn{7}{|c|}{2018 Taxes by Standard or Itemized Deduction } \\
\hline$\$ 24.000$ (Standard) & $-\$ 1.261$ & $\$ 1.739$ & $\$ 4.599$ & $\$ 10.099$ & $\$ 15.599$ & $\$ 21.099$ \\
\hline$\$ 25,000$ & $-\$ 1,381$ & $\$ 1,619$ & $\$ 4,619$ & $\$ 9,879$ & $\$ 15,379$ & $\$ 20,879$ \\
\hline$\$ 30,000$ & $-\$ 1,981$ & $\$ 1,019$ & $\$ 4,019$ & $\$ 8,779$ & $\$ 14,279$ & $\$ 19,779$ \\
\hline \multicolumn{7}{|c|}{ Tax Cut $(-)$ or Increase $(+)$} \\
\hline$\$ 20,000$ & $-\$ 1,261$ & $-\$ 1,152$ & $-\$ 2,042$ & $-\$ 2,335$ & $-\$ 4,329$ & $-\$ 5,079$ \\
\hline$\$ 25,000$ & $-\$ 1,381$ & $-\$ 522$ & $-\$ 1,272$ & $-\$ 1,305$ & $-\$ 3,299$ & $-\$ 4,049$ \\
\hline$\$ 30,000$ & $-\$ 1,981$ & $-\$ 372$ & $-\$ 1,122$ & $-\$ 1,155$ & $-\$ 3,149$ & $-\$ 3,899$ \\
\hline \multicolumn{7}{|c|}{ Breakeven Itemized Deduction } \\
\hline$\$ 20,000$ & $\$ 13,492$ & $\$ 14,400$ & $\$ 14,718$ & $\$ 13,386$ & $\$ 4,325$ & $\$ 916$ \\
\hline$\$ 25,000$ & $\$ 13,492$ & $\$ 20,650$ & $\$ 14,400$ & $\$ 19,068$ & $\$ 10,007$ & $\$ 6,598$ \\
\hline$\$ 30,000$ & $\$ 13,492$ & $\$ 26,900$ & $\$ 20,650$ & $\$ 24,750$ & $\$ 15,689$ & $\$ 12,280$ \\
\hline
\end{tabular}

Table 8

Differences in Taxes Married Filing Jointly with 5 Children using Itemized Deductions

\begin{tabular}{|c|c|c|c|c|c|c|}
\hline $\begin{array}{l}\text { Adjusted Gross Income/ } \\
\text { Itemized Deduction }\end{array}$ & $\$ 50,000$ & $\$ 75,000$ & $\$ 100,000$ & $\$ 125,000$ & $\$ 150,000$ & $\$ 175,000$ \\
\hline \multicolumn{7}{|c|}{2017 Taxes by Itemized Deduction } \\
\hline$\$ 20.000$ & $\$ 0$ & $\$ 0$ & $\$ 1.819$ & $\$ 6.396$ & $\$ 13.890$ & $\$ 21.390$ \\
\hline$\$ 25,000$ & $\$ 0$ & $\$ 0$ & $\$ 1,069$ & $\$ 5,569$ & $\$ 12,646$ & $\$ 20,140$ \\
\hline$\$ 30,000$ & $\$ 0$ & $\$ 0$ & $\$ 319$ & $\$ 4,819$ & $\$ 11,390$ & $\$ 18,890$ \\
\hline \multicolumn{7}{|c|}{2018 Taxes by Standard or Itemized Deduction } \\
\hline$\$ 24.000$ (Standard) & $-\$ 7.000$ & $-\$ 4.261$ & $-\$ 1.401$ & $\$ 4.099$ & $\$ 9.599$ & $\$ 15.099$ \\
\hline$\$ 25,000$ & $-\$ 7,000$ & $-\$ 4,381$ & $-\$ 1,381$ & $\$ 3,879$ & $\$ 9,379$ & $\$ 14,879$ \\
\hline$\$ 30,000$ & $-\$ 7,000$ & $-\$ 4,981$ & $-\$ 1,981$ & $\$ 2,779$ & $\$ 8,279$ & $\$ 13,779$ \\
\hline \multicolumn{7}{|c|}{ Tax Cut (-) or Increase (+) } \\
\hline$\$ 20,000$ & $-\$ 7,000$ & $-\$ 4,261$ & $-\$ 3,220$ & $-\$ 2,297$ & $-\$ 4,291$ & $-\$ 6,291$ \\
\hline$\$ 25,000$ & $-\$ 7,000$ & $-\$ 4,381$ & $-\$ 2,450$ & $-\$ 1,690$ & $-\$ 3,267$ & $-\$ 5,261$ \\
\hline$\$ 30,000$ & $-\$ 7,000$ & $-\$ 4,981$ & $-\$ 2,300$ & $-\$ 2,040$ & $-\$ 3,111$ & $-\$ 5,111$ \\
\hline \multicolumn{7}{|c|}{ Breakeven Itemized Deduction } \\
\hline$\$ 20.000$ & $-\$ 34.333$ & $-\$ 11,508$ & $\$ 9.364$ & $\$ 13.559$ & $\$ 4.495$ & $-\$ 4.595$ \\
\hline$\$ 25,000$ & $-\$ 33,333$ & $-\$ 11,508$ & $\$ 4,583$ & $\$ 17,318$ & $\$ 10,150$ & $\$ 1,086$ \\
\hline$\$ 30,000$ & $-\$ 28,333$ & $-\$ 11,508$ & $\$ 10,833$ & $\$ 20,727$ & $\$ 15,859$ & $\$ 6,768$ \\
\hline
\end{tabular}

\section{CONCLUSION}

A consensus definition of the middle class is elusive; the middle class should be defined somewhere above the poverty line of $\$ 25,000$ but below $\$ 200,000$ of adjusted gross income. This research shows the tax cuts and jobs act provides income tax relief in almost all scenarios to both single and married taxpayers whose incomes range from $\$ 25,000$ to $\$ 175,000$. Tax savings increase from lower marginal tax rates, increased standard deductions, and the vast expansion of the child tax credit, which is arguably the most beneficial of the tax law changes. Families that have children under the age of 17 benefit the most due to the potential refunds from the child tax credit. 
Although personal exemptions have been eliminated in 2018, taxpayers who take the standard deduction see decreases in their tax liability due to the doubling of the standard deduction and lower marginal tax rates. Single taxpayers and married couples filing jointly with no children have proportional tax savings based on their adjusted gross incomes. The federal government has eliminated the marriage tax penalty for the middle class.

Even taxpayers who itemized deductions in 2018 will see tax relief in 2018. In almost all scenarios, the tax liability will decrease. However, taxes will increase for lowincome single and married filing jointly taxpayers without children if they have potentially large amounts of itemized deductions. The probability of these occurrences is small, but still possible. Overall, the tax cuts and jobs act not only benefits businesses, the wealthy, but also the middle class.

\section{REFERENCE}

Bricker, J., Dettling, L. J., Henriques, A., Hsu, J. W., Jacobs, L., Moore, K. B., Pack, S., Sabelhaus, J., Thompson, J., \& Windle, R. A. (2017, September). Changes in U.S. family finances from 2013 to 2016: Evidence from the survey of consumer finances. Federal Reserve Bulletin, 103(3), 1-42. Retrieved November 22, 2017, from https://www.federalreserve.gov/publications/files/scf17.pdf.

Brown, A. (2016, February 4). What Americans say it takes to be middle class. Washington, D.C.: Pew Research Center. Retrieved November 22, 2017, from http:/ /www.pewresearch.org/fact-tank/2016/02/04/what-americans-say-ittakes-to-be-middle-class/.

Desilver, D. (2017, October 6). A closer look at who does (and doesn't) pay U. S. income tax. Washington, D.C.: Pew Research Center. Retrieved January 24, 2018, from http:/ /www.pewresearch.org/fact-tank/2017/10/06/a-closer-look-at-who-does and-doesnt-pay-u-s-income-tax/.

Emmons, W. R., \& Noeth, B. J. (2015, April). The middle class may be under more pressure than you think. St. Louis, MO: Federal Reserve Bank of St. Louis. Retrieved November 22, 2017, from https://www.stlouisfed.org/publications/in-thebalance/issue11-2015/the-middle-class-may-be-under-more-pressure-than-youthink.

Hendrie, A. (2017, December 18). The left is wrong: The tax cuts and jobs act benefits the middle class. Washington Examiner. Retrieved January 24, 2018, from https:/ / www.washingtonexaminer.com/the-left-is-wrong-the-tax-cuts-and-jobsact-benefits-the-middle-class.

IRS. (2017a, September). SOI tax stats-individual income tax return publication 1304. Retrieved January 24, 2018, from https://www.irs.gov/statistics/soi-tax-statsindividual-income-tax-returns-publication-1304-complete-report\#_pt1.

IRS. (2017). 2017 Federal tax rates, personal exemptions, and standard deductions. Retrieved January 24, 2018, from https://www.irs.com/articles/2017-federal-tax-ratespersonal-exemptions-and-standard-deductions.

Joint Committee on Taxation. (2018, April 24). Tables related to the federal tax system as in effect 2017 through 2016. Retrieved May 18, 2018, from https:/ / www.jct.gov/publications.html? func=startdown\&id=5093.

Kessler, G. (2018, January 12). Is the trump tax cut good or bad for the middle class? The Washington Post. Retrieved May 18, 2018, from https://www.washingtonpost.com/news/fact-checker/wp/2018/01/12/is-thetrump-tax-cut-good-or-bad-for-the-middle-class/?utm_term $=.7 \mathrm{bc} 84 \mathrm{f} 1 \mathrm{ddbe} 1$. 
Kochhar, R. \& Morin, R. (2014, January 27). Despite recovery, fewer Americans identify as middle class. Washington, D.C.: Pew Research Center. Retrieved May 18, 2018, from http://www.pewresearch.org/fact-tank/2014/01/27/despite-recoveryfewer-americans-identify-as-middle-class/.

Pew Research Center. (2015, December 9). The American middle class is losing ground: No longer the majority and falling behind financially. Washington, D.C: Pew Research Center. Retrieved November 22, 2017, from http://www.pewsocialtrends.org/ 2015/12/09/the-american-middle-class-is-losing-ground/.

Reeves, R. V., Guyot, K., \& Krause, E. (2018, May 8). A dozen ways to be middle class. The Brookings Institute. Retrieved May 18, 2018, from https://www.brookings.edu/interactives/a-dozen-ways-to-be-middle-class/.

Tax Foundation. (2016, February 4). New IRS data: Wealthy paid 55 percent of income taxes in 2014. Retrieved November 22, 2017, from https://taxfoundation.org/newirs-data-wealthy-paid-55-percent-income-taxes-2014/.

U. S. Census Bureau. (2017). Current population survey (CPS). Annual Social \& Economic Supplements. Retrieved January 24, 2018, from https://www.census.gov/programs-surveys/cps.html.

Varner, C. (2012, October 24). Definition of middle class grows murky. The Pantagraph. Retrieved November 22, 2017, from http:/ / my.ilstu.edu/ cvarne2/PDF/2012/Oct24.pdf.

Williams, G. (2014, April 24). What it means to be middle class today? U. S. News \& World Report. Retrieved November 22, 2017, from https://money.usnews.com/money/personal-finance/articles/2014/04/24/ what-it-means-to-be-middle-class-today.

Yen, H. (2012, July 18). What does it mean to be 'middle class? The Christian Science Monitor. Retrieved November 22, 2017, from https://www.csmonitor.com/USA/Latest-News-Wires/2012/0718/What-doesit-mean-to-be-middle-class. 